\title{
Late complications in patients with intestinal ostomies who underwent a preoperative site marking
}

\section{Complicações tardias em pacientes com estomias intestinais submetidos à demarcação pré-operatória}

\section{Complicaciones tardías en pacientes con estomas intestinales sometidos a la demarcación preoperatoria}

Magali Thum*, Maria Angela Boccara de Paula', Ana Beatriz da Silva Pinto Morita², Aline Lino Balista ${ }^{1}$, Ednalda Maria Franck ${ }^{3}$, Pamella Cristina de Carvalho Lucas ${ }^{1}$

ORCID IDS

Thum M (D) https://orcid.org/0000-0003-3240-2226

Paula MAB ID https://orcid.org/0000-0002-7438-9595

Morita ABSP (iD https://orcid.org/0000-0001-6923-1112

Balista ALB (iD https://orcid.org/0000-0003-0112-9175

Franck EM (iD https://orcid.org/0000-0001-7359-4821

Lucas PCC (iD http://orcid.org/0000-0003-3661-3290
HOW TO CITE

Thum M; Paula MAB; Morita ABSP; Balista AL; Franck EM; Lucas PCC. Late complications in patients with intestinal ostomies who underwent a preoperative site marking. ESTIMA, Braz. J. Enterostomal Ther., 16:e4218. https://doi/org/10.30886/estima.v16.660 IN

\begin{abstract}
Objectives: Describe late complications related to intestinal ostomies in patients undergoing a preoperative site marking. Method: Descriptive study with a quantitative approach. The convenience sample and was composed of 15 people with intestinal ostomies who underwent a preoperative site marking. Data collection was performed between January and March 2014 through a pre-established script that guided the physical examination and a questionnaire containing 13 questions related to the sociodemographic profile, diagnosis, and preoperative site marking. Results: It was verified that in 13 (87.7\%) people who had site marked ostomies, it was located at a distance of more than $5 \mathrm{~cm}$ of surgical scars, iliac crest, umbilical scar, and waistline. Two people with ileostomy (13.3\%) had intestinal loop protrusion short of recommended. Regarding postoperative complications, three participants (20\%) presented peristomal dermatitis and one (6.7\%), in addition to dermatitis, prolapse of the ostomy. Conclusion: The study showed that the postoperative complications reported by patients who underwent a preoperative stomatal site marking were poorly observed and that these was consisted of peristomal dermatitis and prolapse of the ostomy.
\end{abstract}

DESCRIPTORS: Ostomy; Preoperative site marking; Post-Operative Complications; Nursing; Stomatherapy.

\footnotetext{
${ }^{1}$ Universidade de Taubaté - Departamento de Enfermagem e Nutrição - Pró Reitoria Pesquisa e Pós-Graduação - Taubaté/SP - Brazil. ${ }^{2}$ Centro Universitário Teresa D’Ávila - Faculdade de Enfermagem - Lorena/SP - Brazil.

3Universidade de São Paulo - Faculdade de Medicina - Núcleo Técnico Científico em Cuidados Paliativos - São Paulo/SP - Brazil. Correspondence author: Magali Thum | Rua Claro Gomes, 112. Apart. 32 | ZIP Code: 12010-520 - Taubaté/SP - Brazil.

E-mail: magali.thum@gmail.com

Received: Oct 292018 | Accepted: Jan 232019
} 


\section{RESUMO}

Objetivo: Descrever as complicações tardias relacionadas às estomias intestinais em pacientes submetidos à demarcação pré-operatória. Método: Estudo descritivo com abordagem quantitativa. A amostra foi de conveniência e composta por 15 pessoas com estomias intestinais submetidas à demarcação pré-operatória. A coleta de dados foi realizada entre janeiro e março de 2014 por meio de roteiro pré-estabelecido que norteou o exame físico e questionário contendo 13 questões relacionadas ao perfil sociodemográfico, ao diagnóstico e à demarcação pré-operatória. Resultados: Verificou-se que em 13 (87,7\%) pessoas que tiveram estomia demarcada, esta estava localizada a uma distância superior a $5 \mathrm{~cm}$ de cicatrizes cirúrgicas, crista ilíaca, cicatriz umbilical e linha da cintura. Duas pessoas com ileostomia (13,3\%) tinham protrusão da alça intestinal aquém do recomendado. No que se relaciona a complicações pós-operatórias, três participantes (20\%) apresentaram dermatite periestomia e um (6,7\%), além da dermatite, prolapso da estomia. Conclusão: O estudo mostrou que as complicações pós-operatórias relatadas pelos pacientes submetidos à demarcação pré-operatória da estomia foram pouco observadas e essas foram a dermatite periestomia e o prolapso de estomia.

DESCRITORES: Estomia; Demarcação pré-operatória; Complicações Pós-Operatórias; Enfermagem; Estomaterapia.

\section{RESUMEN}

Objetivo: Describir las complicaciones tardías relacionadas a las estomas intestinales en pacientes sometidos a la demarcación preoperatoria. Método: Estudio descriptivo con abordaje cuantitativo. La muestra fue pertinente y fue compuesta por 15 personas con estomas intestinales sometidas a la demarcación preoperatoria. La recolección se realizó entre enero y marzo de 2014 por medio de un itinerario preestablecido que condujo el examen físico y un cuestionario conteniendo 13 preguntas relacionadas al perfil sociodemográfico, al diagnóstico y a la demarcación preoperatoria. Resultados: Se verificó que en 13 (87,7\%) personas que tuvieron estoma demarcada, la misma estaba localizada a una distancia superior a $5 \mathrm{~cm}$ de cicatrices quirúrgicas, crista ilíaca, cicatriz umbilical y línea de la cintura. Dos personas con ileostomía (13,3\%) tenían protrusión de alza intestinal por debajo de lo recomendado. En lo relacionado a complicaciones posoperatorias, tres participantes (20\%) presentaron dermatitis periestoma y uno (6,7\%), además de la dermatitis, prolapso de estoma. Conclusión: El estudio mostró que se observaron pocas complicaciones posoperatorias relatadas por los pacientes sometidos a la demarcación preoperatoria de la estoma y que las mismas constaron de dermatitis periestoma y prolapso de estoma.

DESCRIPTORES: Estoma; Demarcación preoperatoria; Complicaciones Posoperatorias; Enfermería; Estomaterapia.

\section{INTRODUCTION}

The procedure of preoperative site marking of intestinal ostomies, with its importance to prevent complications, was defined by the United Ostomy Association (UOA), in 1993, as one of the rights of the person with an ostomy ${ }^{1}$.

The site marking consists of the procedure of choosing the best place for exteriorization of the future ostomy, being pointed as an impacting factor in the physical and emotional rehabilitation of the patient ${ }^{2}$, because it favors better conditions for self-care and reduces the chances of leakage of the effluent to the skin, thereby reducing the incidence of peristomal lesions. It also contributes to the resumption of social life, since many complications can be avoided ${ }^{3,4}$.

The site marking should be performed by the Enterostomal Therapist (ET) nurse, by the doctor who will perform the surgery $y^{2,5}$ or by the nurse trained for such activity ${ }^{3}$. The patient, at the end of the procedure, should be able to visualize the whole demarcated area, which will facilitate self-care and, with this, the reduction of complications $\mathbf{s}^{2,5,6}$.

In relation to the complications, those that occur within the first 24 hours after confection are immediate, and among them, there may be necrosis and edema of the stomach, bleeding or hemorrhage ${ }^{7,8}$. Between the first and the seventh postoperative day, early complications such as ostomy retraction and cutaneomucous separation may occur. However, late complications can occur, such as intestinal loop prolapse, stomatal stenosis, stomatal retraction, and paraestomic hernia ${ }^{7,8}$.

It is important to point out that complications in the skin peristomy are also worthy attention, among them peristomal dermatitis, which is one of the most prevalent complications and its causes are varied ${ }^{8,9}$. 
The most common cause of dermatitis is the inadequate adhesion of the collecting equipment to the abdominal wall, causing leakage of effluent on the peristomal skin. The factors that contribute to its development are associated, for the most part, with the poor location of the ostomy or even with the mistaken choice of the collecting system ${ }^{10}$.

The Wound, Ostomy and Continence Nurses Society, the American Society of Colon and Rectal Surgeons and the American Urological Association ${ }^{2}$ recommend that all persons who underwent a manufacture of the ostomy should have the externalization place previously marked, including those which confection is still a possibility or the ostomy is temporary.

Preoperative site marking of stomates considerably reduces the occurrence of postoperative complications, however, in the Brazilian reality, there are still missing studies that show which complications cease to occur and which still occur even in patients who underwent the procedure.

\section{OBJECTIVES}

To analyze late complications related to intestinal ostomies in patients who underwent a preoperative site marking.

\section{METHOD}

Descriptive research with a quantitative approach, performed with people who lived with an ostomy and underwent a preoperative site marking registered in an association of people with ostomies from the interior of the state of São Paulo (Brazil).

The sample was of convenience for those patients registered, active and with contacts updated in the period from January to March of 2014.

To identify the sample, telephone contact was made with people with the objective of ascertaining if their ostomy had been demarcated before the surgery. The telephone interview was guided by a previously established script: initially, the purpose of the contact was presented and the participant was invited to answer two questions - the first was to ask whether the person had been undergoing a preoperative site marking of the ostomy; if not, the call was ended at this time; if so, the person was invited to participate in the study.

The inclusion criteria were to be older than 18 years and to be available for collection at home. Those who did not answer the call until the third attempt or did not have up-to-date telephone contact in the associations registry were excluded from the study.

All demarcated associates contacted accepted to participate in the study.

The data collection was performed through a physical examination that focused on the abdomen of the person with the ostomy, being guided by a previously defined form.

At the moment, the following questions were evaluated: the distance in centimeters from the ostomy to the umbilical scar, the iliac crest, the waistline, skin folds, and other scars, when present, and the protrusion of the stoma in relation to the skin, with the help of a measuring tape. Through palpation, it was identified whether the ostomy was externalized under the abdominal rectus muscle.

Subsequently, a form containing 13 questions related to the participant profile was used: age, gender, educational level, professional occupation, time and reason for making the ostomy and its site marking. It was also asked if they developed complications related to the ostomy and how long after the surgery they occurred.

The data collected were tabulated, presented in tables, in the form of absolute numbers and percentages, and analyzed in a descriptive way in the light of the literature on the subject in question.

The ethical and legal aspects were strictly followed. The research was approved by the Research Ethics Committee of the University of Taubaté, under opinion no. 269,538, and followed the determinations of National Health Council Resolution 466, of December 12, 201211, related to research involving human beings.

\section{RESULTS}

The sample consisted of 15 people who underwent the preparation of intestinal stomies and the preoperative site marking. Four (26.7\%) were male and 11 (73.3\%) were female. When analyzing the age according to sex, 
the mean in the male group was higher, 70 years; among women, the average was 60.3 years.

It was found that eight people (53.3\%) were over 61 years of age and that eight (53.3\%) had an incomplete elementary education. It should be noted that none of the respondents had completed tertiary education. With regard to professional activity, nine $(60 \%)$ were retired and three $(20 \%)$ were dedicated to domestic skills. Other professions have been reported: seller, marketer, and maid.

Analyzing the reason for making the stoma, nine people $(60 \%)$ went through this procedure due to colorectal cancer. There were predominant confections of cancer-related tumors in women, totaling six cases (40\%) (Table 1).

The study shows that nine people $(60 \%)$ had been living with the ostomies for six years or more. When assessing the time of coexistence according to gender, it is observed that four women (26.7\%) had the ostomy between two and five years. Among men, this time was longer, more than six years (Table 2).

Regarding the type of ostomy made in the preoperative population, ten (66.7\%) had a colostomy and five (33.3\%) had an ileostomy. In this study, $100 \%$ of the population had a definite ostomy.

The present study revealed that seven (46.7\%) were demarcated 24 hours prior to surgery, in relation to the period that elapsed between the site marking of the ostomy and its confection; four (26.7\%), 48 hours before; one (6.7\%) had the ostomy demarcated on the day of their manufacture; and three (20\%) did not know how to inform.

During the physical examination, it was possible to perform the palpation of the abdominal rectum muscle in all the subjects and the whole had the ostomy externalized in said muscle.

Table 3 shows the results collected during the physical examination and aimed to determine if the minimum distance of 4 to $5 \mathrm{~cm}$ from the critical points, such as waistline, surgical scar, and bony prominences, was observed during the procedure, since this is the distance recommended in the literature ${ }^{12}$ and contributes to the correct adaptation of the collection equipment in the peristomal region.

Table 4 shows the data on the protrusion of the ostomy in relation to the cutaneous plane. It was verified

Table 1. Distribution of the interviewees who underwent a preoperative site marking of the stomies, according to gender and diagnosis. Taubaté, São Paulo, Brazil, 2014.

\begin{tabular}{|c|c|c|c|}
\hline \multirow{2}{*}{$\begin{array}{l}\text { Reason for the confection of } \\
\text { intestinal ostomy }\end{array}$} & Female & Male & Total \\
\hline & \multicolumn{3}{|c|}{$\mathrm{n}(\%)$} \\
\hline Colorectal cancer & $6(40)$ & $3(20)$ & $9(60)$ \\
\hline Inflammatory bowel disease & $1(6.7)$ & $1(6.7)$ & $2(13.3)$ \\
\hline Diverticular disease & $1(6.7)$ & $0(0)$ & $1(6.7)$ \\
\hline Colorectal trauma & $1(6.7)$ & $0(0)$ & $1(6.7)$ \\
\hline Congenital disease & $0(0)$ & $0(0)$ & $0(0)$ \\
\hline Large bowel obstruction & $0(0)$ & $0(0)$ & $0(0)$ \\
\hline Other causes & $2(13.3)$ & $0(0)$ & $2(13.3)$ \\
\hline Do not know/do not remember & $0(0)$ & $0(0)$ & $0(0)$ \\
\hline Total & $11(73.4)$ & $4(26.7)$ & $15(100)$ \\
\hline
\end{tabular}

Table 2. Numerical distribution and percentage of the participants according to the time of confection of the ostomy. Taubaté, São Paulo, Brazil, 2014.

\begin{tabular}{|c|c|c|c|}
\hline Time (years) & Female & Male & Total \\
\hline of ostomy confection & & $\mathrm{n}(\%)$ & \\
\hline 0 to 1 & $2(13.3)$ & $0(0)$ & $2(13.3)$ \\
\hline 2 to 5 & $4(26.7)$ & $0(0)$ & $4(26.7)$ \\
\hline 6 to 10 & $3(20)$ & $2(13.3)$ & $5(33.3)$ \\
\hline$>10$ & $2(13.3)$ & $2(13.3)$ & $4(26.7)$ \\
\hline Tottol & $11(73.3)$ & $4(26.6)$ & $15(100)$ \\
\hline
\end{tabular}


Table 3. Numerical distribution and percentage of participants who underwent a preoperative site marking arcation, according to the minimum distance of $5 \mathrm{~cm}$ from the ostomy in relation to the critical areas. Taubaté, São Paulo, Brazil, 2014.

\begin{tabular}{|c|c|c|c|c|c|}
\hline \multirow{2}{*}{$\begin{array}{l}5 \mathrm{~cm} \text { distance } \\
\text { from critical areas }\end{array}$} & Scars & Skinfolds & Iliac crest & Umbilical scar & Waistline \\
\hline & \multicolumn{5}{|c|}{$\mathrm{n}(\%)$} \\
\hline Yes & $13(86.7)$ & $10(66.7)$ & $13(86.7)$ & $13(86.7)$ & $13(86.7)$ \\
\hline No & $2(13.3)$ & $5(33.3)$ & $2(13.3)$ & $2(13.3)$ & 2 (13.3) \\
\hline Total & $15(100)$ & $15(100)$ & $15(100)$ & $15(100)$ & $15(100)$ \\
\hline
\end{tabular}

Source: Research data

Table 4. Numerical distribution and percentage of participants with intestinal elimination stomies according to height, in millimeters, relative to skin level. Taubaté, São Paulo, Brazil, 2014.

\begin{tabular}{|c|c|c|c|}
\hline \multirow{2}{*}{$\begin{array}{l}\text { Height of the ostomy in relation } \\
\text { to the level of the skin }(\mathrm{mm})\end{array}$} & Ileostomy & Colostomy & Total \\
\hline & \multicolumn{3}{|c|}{ n (\%) } \\
\hline$\leq 09$ & $0(0)$ & $3(20)$ & $3(20)$ \\
\hline Between 10 and 19 & $1(67)$ & $4(26.7)$ & $5(33.4)$ \\
\hline Between 20 and 29 & $1(67)$ & $3(20)$ & $4(26.7)$ \\
\hline Between 30 and 39 & $0(0)$ & $0(0)$ & $0(0)$ \\
\hline Between 40 and 49 & $1(67)$ & $0(0)$ & $1(67)$ \\
\hline$\geq 50$ & $2(13.3)$ & $0(0)$ & $2(13.3)$ \\
\hline Total & $5(33.4)$ & $10(66.7)$ & $15(100)$ \\
\hline
\end{tabular}

Source: Research data.

that in 13 people (86.7\%), the ostomy was located more than $5 \mathrm{~cm}$ away from surgical scars, iliac crest, umbilical scar, and waistline.

When evaluating the distance of the ostomy from the skin folds, the data obtained show that in ten people (66.7\%), the minimum distance was observed, showing that in relation to the other critical areas, this percentage was lower.

The data revealed that of the five patients with an ileostomy, two (13.3\%) had intestinal loop protrusion of less than $30 \mathrm{~mm}$.

When evaluating the protrusion of the ostomy in patients with a colostomy, three (20\%) had stoma with less than $10 \mathrm{~mm}$ of protrusion, resulting in a stoma very close to the skin level.

Listing the complications experienced by people who underwent a preoperative site marking is of paramount importance to qualify the assistance provided. In this study, three people (20\%) had complications.

All three (100\%) presented peristomal dermatitis and one (33.3\%), in addition to dermatitis, presented prolapse with about $30 \mathrm{~cm}$ protrusion of the intestinal loop.

The professional most referenced by the participants who underwent the procedure of demarcating the ostomy in the preoperative period was the physician, responsible for demarcating 11 (73.3\%) patients. However, three
(20\%) reported not remembering the professional who performed the procedure and only one patient (6.7\%) reported that the procedure was done by the ET nurse.

\section{DISCUSSION}

This study shows colorectal neoplasia as the prevailing diagnosis, leading to the creation of nine ostomies (60\%), and in the female gender, it was the main reason, with six ostomies made (40\%). This finding is in line with other results found in similar studies that indicate a greater number of women being diagnosed with colorectal cancer when compared to the same diagnosis in the male group ${ }^{13,14}$.

This scenario will, it seems, remain similar, since for each year of the 2018-2019 biennium the estimate is 36,360 new cases of colorectal cancer, 17,380 in men and 18,980 in women. This is the third most common type of cancer among men and the second most common cancer among women. Without considering nonmelanoma skin tumors, colon and rectum cancer in men is the second most frequent in the Southeast Region of Brazil (23.29/100 thousand) ${ }^{15}$.

In view of the above, it can be observed that colorectal cancer continues to be the main cause of intestinal 
ostomies confection and is considered an important problem to be solved in public health.

It is important to emphasize that educational measures must be carried out so that the population prevents the onset of cancer and, in cases in which it is not possible to work in the prevention of the disease, to identify early signs and symptoms of its development.

In this perspective, the ET nurse assumes an important role, that of educator, and must act as a team with the community both in cancer prevention and in the prevention of diseases caused by cancer.

In cases in which early diagnosis is not possible, the ET nurse should assume the role of guiding and demarcating the stoma in the preoperative consultation, minimizing the occurrence of complications due to the confection of the ostomy ${ }^{2,5,16,17}$.

As the preoperative site marking procedure is part of the ET nurse consultation, guidance is essential; and researching the level of education of the patient becomes essential when thinking about maintaining or even improving the quality of life of people in the postoperative period. In this study, eight (53.3\%) participants had incomplete elementary education; it should be noted that none of the respondents had completed higher education.

Other stidies ${ }^{13,17,18}$ show the predominance of this same level of education. The authors emphasize that the degree of education is considered a worrying factor due to clarifications about the disease and the treatment that are necessary, which may compromise patients adherence to self-care, since the low level of schooling may reflect negatively in the way of assimilating the guidance on care with the ostomy.

The ability of people to understand the information provided by the ET nurse can be hampered by a low level of education. Another important point that may occur is the low capacity for questioning how it will adapt to the new health condition, generating problems and also problems related to self-care.

Health professionals working with people who undergo through ostomies confection should adjust their communication, be it oral, written and even playful, during the preoperative consultation so that the person is able to appropriate the guidelines that the possibility to develop the self-care necessary to maintain the same autonomy as before the procedure ${ }^{19}$.
In relation to the time of coexistence with the ostomy, nine (60\%) people lived with a stoma for more than six years. It is known that adaptation to the condition of living with it is not something simple and fast, on the contrary, it is a long and continuous process and extremely related to the basic illness, the degree of incapacity, the individual values and the type of personality of the patient ${ }^{3}$.

When evaluating the type of stoma made, the predominance of patients with a colostomy is in agreement with other studies that point to these same indexes ${ }^{18}$; in addition to this, the present study revealed that all had definite estomies.

Probably there is a relationship between this data, the predominant age group and the cause of the stomatal confection, considering that, as the population grows older, increases the risk of chronic degenerative diseases, such as colorectal cancer, the main cause of intestinal ostomies ${ }^{13}$.

It is known that, ideally, the ostomy should be demarcated 24 hours before the surgery, so that the patient is able to participate in the choice of place to be made. The participation of the patient in the site marking can be impaired when it occurs immediately before the surgery since the emotional factor can interfere negatively in this process ${ }^{2}$.

When the stoma is demarcated more than 48 hours in advance, the demarcated area should be protected with clear polyurethane film, avoiding that the marking should come out during corporal hygiene ${ }^{10}$. In this study, just under half $(46.7 \%)$ of the patients had access to the site marking in the period considered ideal.

The exteriorization of the ostomy under the abdominal rectum muscle is one of the predictors of preoperative site marking since it reduces late complications, such as prolapse and peristomal hernia ${ }^{5,10}$. Numbers raised to indicate that all 15 patients (100\%) had this requirement observed by the professional who performed the site marking.

In addition to the care of demarcating the ostomy over the abdominal rectum muscle, other points should be observed during the site marking, in order to minimize postoperative complications, with a minimum distance of $5 \mathrm{~cm}$ from critical areas such as surgical scars, skin folds, iliac crest, umbilical scar, and waistline ${ }^{10}$.

Table 3 shows that the minimum distance of 4 to $5 \mathrm{~cm}$ was observed in 13 patients $(86.7 \%)$ during the 
site marking procedure in relation to the following critical areas: surgical scars, iliac crest, umbilical scar, and waistline. However, when the minimum distance from the skin folds was evaluated, this number was reduced to 10 patients $(66.6 \%)$. It is important to point out that the patient undergoing intestinal ostomy, also undergoes a process of weight loss, which is accentuated depending on the diagnosis.

After the connection of the ostomy, the patient regains his health and returns to gain body weight, causing the abdominal anatomy to acquire new forms; the appearance of cutaneous folds, which is intrinsic to weight gain, is a factor that may justify the lower percentage of observance of the minimum distance of $5 \mathrm{~cm}$ related to this critical area.

It is up to the professional that performs the site marking to identify risk factors and to act in a multidisciplinary team to minimize postoperative complications as a consequence of excessive weight gain or decrease, since these can cause early detachment of the collecting equipment, contributing to the appearance of peristomal dermatitis, which is one of the most common complications in people with ostomies.

When evaluating the protrusion of the intestinal loop over the cutaneous plane in patients with an ileostomy, it is observed that of the five patients with an ileostomy, two had a protrusion of the ostomy smaller than $3 \mathrm{~cm}$.

Making an ileostomy with protrusion between 3 and $5 \mathrm{~cm}$ favors the reduction of complications such as peristomal dermatitis since the effluent is drained into the collection pouch, preventing its infiltration between the adhesive plate of the equipment and the skin, the main cause of this dermatitis. Even not observing this recommendation, the referred patients did not report dermatitis as an experienced complication 10 .

Three participants with a colostomy (20\%) had a stoma with a smaller height than the one recommended. This fact is not a problem when one thinks of prevention of dermatitis in colostomy patients since the effluent exonerated in this intestinal segment has a $\mathrm{pH}$ closer to that of the skin, which significantly reduces the occurrence of peristomal dermatitis ${ }^{19}$. On the other hand, the other patients with a colostomy had the height of the stoma inside the recommended one.

In view of these results, it was observed that the site marking procedure was performed adequately in the great majority of the participants, demonstrating that the professionals who performed the procedure had the scientific knowledge that supported the choice of the best place to externalize the intestinal loop. However, the fact that the patient undergoes preoperative site marking of the ostomy does not totally exempt them from experiencing postoperative complications

.It was observed that one participant (33.3\% of those who presented complications) presented prolapse, with about $30 \mathrm{~cm}$ of intestinal loop protrusion and peristomal dermatitis. One of the ways to prevent prolapse is the exteriorization of the ostomy under the abdominal rectum muscle, that provides the needed muscular support ${ }^{3}$.

The presence of prolapse makes it difficult to adapt the collecting equipment to the skin, since in these cases it is necessary to use equipment whose base is flexible, with a clipping area and fixation larger than the usual average. The storage capacity of the pouchs should also be higher. In many cases, it is convenient to use accessories and adjuvants such as resin-based paste protectors or cutaneous protectors in the peristomal region ${ }^{10}$.

Another complication evidenced was peristomal dermatitis, reported by three patients. Dermatitis is one of the most frequent complications in patients with an ostomy $^{8,9,20,21}$. It can be defined as an acute or chronic process, whether or not accompanied by rupture of integument integrity, affecting the area of peristomal skin ${ }^{9}$.

The main triggering factors of dermatitis are in contact with the effluent of the peristomal skin, effluent from the ileostomy or colostomy, allergy to the components of the collecting equipment, mechanical trauma and infection? ${ }^{7}$.

It should be pointed out that one of the forms of prevention of peristomal dermatitis should be done in the period before the surgery to generate the ostomy, by means of the site marking, since the good location of the ostomy makes self-care and rehabilitation easier?

In addition to the site marking, another factor that contributes positively to the maintenance of the integrity of the peristomal skin is the proper orientation of the patient/caregiver on the correct procedures for the care of the ostomy and the peristomal skin in the period before discharge ${ }^{9}$.

Searching to know which professionals performed the site markings, this study indicates that 11 people $(73.3 \%)$ had 
the procedure performed by the medical professional, who is also indicated for this procedure ${ }^{5}$. However, three (20\%) reported not remembering the professional who performed the procedure and only one patient $(6.7 \%)$ reported that it was performed by the ET nurse.

This data reveals an important aspect regarding the performance of the ET professional in the care of patients who underwent a manufacture of ostomies. It is alarming to note that only one patient had their ostomy demarcated by the ET nurse, who is the most appropriate professional to perform this procedure ${ }^{3,5}$.

It is known that, in the absence of the ET nurse, this procedure can and should be performed by a trained nurse, but many nurses who work in this care segment are still unaware of the existence of the technique and its importance ${ }^{22}$. In a study carried out in 1981, the author already indicated as a problem the low number of people demarcated in the preoperative period, stating that the site marking is neglected by Brazilian nurses ${ }^{23}$.

After more than 30 years, this reality does not seem to have changed and opens space for reflections on how nurses in their workspace can plan and systematize nursing care in an individualized way, in order to promote an efficient rehabilitation of the patient that requires the making of an ostomy, aimed at self-care and the minimization of postoperative complications.

It can not be denied that the number of ETnurses working in hospital care is still short of what is necessary to meet all the demand, since it develops administrative activities and also in the area of urinary and anal wounds and incontinence, and, for institutional reasons, he often prioritizes administrative issues or even assigns his time of assistance to patients with skin lesions, failing to directly assist patients who undergo the manufacture of intestinal ostomies.

However, the ET nurse should legitimize their practice in the area of care for people with hospital-level stomies, and one of the ways to do this would be to perform procedures that are her responsibility in this specific area, one of them being the site marking of preoperative bowel ostomies.

It is important to emphasize that the care and guidance of people with intestinal ostomies are extremely important interpersonal practices for individualized quality care, and, in this context, the preoperative stomatal site marking is included, since it represents a decisive procedure for the process of rehabilitation of the person ${ }^{24}$.

The limitations of this study are related to the difficulty in locating, through telephone contact, its participants, since the files of this association was outdated, making it impossible to contact a larger number of people with ostomies that could meet the study criteria, which prevented this research from being performed with a larger number of participants.

\section{CONCLUSION}

The present study identified that complications related to patients who underwent a site marking were dermatitis and intestinal loop prolapse. It is known that preoperative site marking of stomies is a procedure that does not fully guarantee the absence of postoperative complications, but contributes to reducing the risk of complications and, thus, cohabitation with the ostomy can become less traumatic when the patient is adequately assisted by the professionals responsible for their treatment.

Thus, the stomaherapist nurse plays an important role in this context, since they must take responsibility for performing this procedure in their area of performance; however, the site marking of the stoma is still, for many nurse practitioners in stomatherapy, little accomplished, often seen only during the completion of the specialization.

In order for a change to take place in this reality, it is necessary that the stimulus to the accomplishment of this procedure occurs in the spaces of formation and assistance, with also practical capacities, since it is a right conquered by the people with ostomies and the ET professional has as duty, in their workspace, to ensure that everyone has access to this procedure, which should be part of the preoperative nursing consultation.

\section{CONTRIBUTION OF AUTHORS}

Contextualization, Thum Me Paula MAB; Metodologia, Thum M; Paula MAB e Morita ABSP; Writing - First version, Thum M; Balista ALB; Franck EM e Lucas PCC; Writing - Reviewing \& Editing, Thum M e Paula MAB. 


\section{REFERENCES}

1. Charter of Ostomates Rights [Internet]. IOA Coordination Committee: International Ostomy Association; 1993 [updated 2007; cited 2018 Sept]. Available at: https:// www.ostomyinternational.org/about-us/charter.html

2. American Society of Colon and Rectal Surgeons; Wound, Ostomy and Continence Nurses Society. ASCRS and WOCN joint position statement on the value of preoperative stoma marking for patients undergoing fecal ostomy surgery. J Wound Ostomy Continence Nurs. 2007;34(6):627-8. https://doi.org/10.1097/01.won.0000299812.08533.a6

3. Cesaretti IUR, Paula MAB. Demarcação do local para abertura da estomia: fundamentos teóricos da prática. In: Cesaretti IUR, Paula MAB, Paula PR, editores. Estomaterapia: temas básicos em estomas. São Caetano do Sul: Yendis; 2014. p. 121-31.

4. WOCN Society Clinical Guideline: Management of the Adult Patient with a Fecal or Urinary Ostomy - An Executive Summary. J Wound Ostomy Continence Nurs. January/February 2018;45(1):50-8 https://doi. org/10.1097/won.0000000000000396

5. World Council of Enterostomal Therapists. WCET International Ostomy Guideline Recommendations. WCET Journal. 2014;34(2).

6. Salvadalena G, Hendren S, McKenna L, Muldoon R, Netsch D, Paquette I, et al. WOCN Society and ASCRS position statement on preoperative stoma site marking for patients undergoing colostomy or ileostomy surgery. J Wound Ostomy Continence Nurs. 2015;42(3):249-52. https://doi.org/10.1097/won.0000000000000119

7. Paula MAB, Cesaretti IUR. Como cuidar de pessoas com estomias complicadas. In: Paula MAB, Paula PR, Cesaretti IUR, editores. Estomaterapia em foco e o cuidado especializado. São Caetano do Sul: Yendis; 2014. p. 169-82.

8. Paula PR, Matos D. Complicações precoces e tardias nas estomias intestinais e pele periestomia. In: Santos VLCG, Cesaretti IUR, editores. Assistência em estomaterapia: cuidando de pessoas com estomias. São Paulo: Atheneu; 2015. p. 311-9.

9. Cesaretti IUR, Santos VLCG. Pele periestomia: prevenção e tratamento de lesão. In: Paula MAB, Paula PR, Cesaretti IUR, editores. Estomaterapia em foco e o cuidado especializado. São Caetano do Sul: Yendis; 2014. p. 133-50.

10. Asociación Mexicana de Cirugía General; Asociación Mexicana del Cuidado Integral y Cicatrización de Heridas. Guía de Práctica Clínica basada en evidencia científica para el marcaje y manejo integral de personas adultas con estomas de eliminación [Internet]; 2011 [cited 2014 Mar]. Available at: https://amcgmx.files.wordpress. com/2012/06/guia estomas 2011.pdf

11. Brasil. Ministério da Saúde. Conselho Nacional de Saúde. Diretrizes e normas regulamentadoras sobre pesquisa envolvendo seres humanos. Resolução n. 466, 12 dezembro 2012. Brasília, 2012.

12. Meirelles CA, Ferraz CA. Avaliação da qualidade do processo de demarcação do estoma intestinal e das intercorrências tardias em pacientes ostomizados.
Rev Latino-Am Enferm. 2001;9(5):32-8. https://doi. org/10.1590/s0104-11692001000500006

13. Ecco L, Dantas FG, Melo MDM, Freitas LS, Medeiros LP, Costa IKF. Perfil de pacientes colostomizados na Associação dos Ostomizados do Rio Grande do Norte. ESTIMA, Braz J Enterostomal Ther. 2018;16 (351). https:// doi.org/10.30886/estima.v16.351_pt

14. Barbosa MR, Simon BS, Tier CG, Garcia RP, Siniak DS, Rodrigues SO. Perfil de pessoas com estomias de um serviço de saúde municipal no Sul do Brasil. ESTIMA, Braz J Enterostomal Ther. 2018;16(1318). https://doi. org/10.30886/estima.v16.465 pt

15. Brasil. Ministério da Saúde. Instituto Nacional de Câncer José Alencar Gomes da Silva. Coordenação de Prevenção e Vigilância. Estimativa 2018: incidência de câncer no Brasil. Rio de Janeiro: INCA; 2017.

16. Colwell JC, Gray M. Does preoperative teaching and stoma site marking affect surgical outcomes in patients undergoing ostomy surgery? J Wound Ostomy Continence Nurs. 2007;34(5):492-6. https://doi.org/10.1097/01. won.0000290726.08323.a6

17. Kamada I, Faustino AM, Silva ALS, Vieira ABD, Borges CT. Conhecimento acerca da Estomia Intestinal por Pacientes Acompanhados em um Serviço Ambulatorial de Enfermagem em Estomaterapia: Estudo Qualitativo. ESTIMA, Braz J Enterostomal Ther. 2011;9(4).

18. Sena JF, Medeiros LP, Melo MDM, Souza AJG, Freitas LS, Costa IKF. Perfil de estomizados com diagnóstico de neoplasias cadastrados em uma associação. Rev Enferm UFPE on line. 2017;11(2):873-80.

19. Duarte AMS. Avaliação da qualidade de vida dos pacientes portadores de estomias intestinais [dissertação]. Alfenas: Universidade José do Rosário Vellano; 2009.

20. Salvadalena GD. The incidence of stoma and peristomal complications during the first 3 months after ostomy creation. J Wound Ostomy Continence Nurs. 2013;40(4):400-6. https://doi.org/10.1097/WON.0b013e 318295a12b

21. Miranda SM, Luz MHBA, Sonobe HM, Andrade EMLR, Moura ECC. Caracterização sociodemográfica e clínica de pessoas com estomia em Teresina. ESTIMA, Braz J Enterostomal Ther. 2016;14(1):29-35. https://doi.org/ 10.5327/Z1806-3144201600010005

22. Andrade DB, Santos CRS. Assistência de enfermagem a pacientes submetidos à confecção de estoma intestinal e urinário em dois hospitais do Sul de Minas Gerais. Congresso Unificado UNILAVRAS - II Fórum Científico do Unilavras; 2013; Lavras/MG, BR.

23. Zerbetto GM. Roteiro para avaliação do nível de problemas do paciente colostomizado [dissertação]. São Paulo: Universidade de São Paulo; 1981.

24. Pinto IES, Queirós SMM, Queirós CDR, Silva CRR, Santos CSVB, Brito MAC. Fatores de risco associados ao desenvolvimento de complicações do estoma de eliminação e da pele periestomal. Rev Enf Ref. 2017;IV(15). https://doi.org/10.12707/RIV17071 